\title{
A LUTA CONTRA A DITADURA CIVIL-MILITAR A PARTIR DA PRÁTICA DA NÃO-VIOLÊNCIA ATIVA
}

\author{
THE STRUGGLE AGAINST THE CIVIL-MILITARY DICTATORSHIP BASED
}

ON THE PRACTICE OF ACTIVE NON-VIOLENCE

ROBERTO ZWETSCH ${ }^{*}$

\begin{abstract}
RESUMO
Desde a preparação do Golpe civil-militar até sua consecução em abril de 1964, as igrejas cristãs contribuíram a favor de sua implantação, inspiradas pelo medo ao comunismo e a possibilidade de um governo popular de esquerda na trilha das Reformas de Base do Governo do Presidente João Goulart. As Marchas da Família com Deus pela Liberdade e o apoio de autoridades eclesiásticas ao Golpe, até mesmo denúncias de religiosos contra pessoas da mesma igreja opositoras do regime, permitem afirmar que o papel das igrejas foi mais que ambíguo. Foi de explícito apoio e comprometimento com seus objetivos. Mas este posicionamento se reverteu, ao menos entre setores minoritários das igrejas, como os grupos progressistas, sobretudo de jovens, que há mais tempo vinham participando dos movimentos de base da sociedade. Não por acaso, reuniões entre teólogos depois conhecidos pela formulação da Teologia da Libertação se deram no Brasil, por exemplo, em Petrópolis, RJ, sede da Editora Vozes. Nesse artigo, o autor destaca em especial a contribuição do Movimento de Não-Violência ativa na oposição e resistência ao regime e sua importância na formação de uma juventude que começava a participar da política sem a experiência dos partidos de esquerda, mas ávida por uma compreensão crítica da sociedade repressora em que vivia naqueles anos.
\end{abstract}

Palavras Chave: Ditadura civil-militar de 1964. Igrejas cristãs. Direitos humanos. Não-

violência ativa. Firmeza-permanente.

\begin{abstract}
The Christian churches explicitly contributed to the success of the civil-military Coup which took place in April of 1964. The Family Marches with God for Freedom and the support of ecclesiastical authorities of the Coup reveal this position and their commitment to the new regime. However, this attitude was counteracted when important sectors of the churches, although in the minority, placed themselves in resistance to the regime and to the decision. For example, some encounters Latin American Theologians' of the Liberation Theology occurred in Petrópolis, Rio de Janeiro, in the Vozes Published House. The article highlights the contribution of the Active Non-Violent Movement in the opposition and resistance toward the regime, as well as its importance in the formation of youth who were beginning to participate in the political scene.
\end{abstract}

KEYWORDS: Civil-military dictatorship of 1964. Christian churches. Human right. Active nonviolence.

\footnotetext{
${ }^{(*)}$ Doutor em Teologia pela Escola Superior de Teologia, São Leopoldo, RS, Brasil. Atualmente é professor na Faculdade EST. Tem experiência na área de Teologia Latino-Americana atuando principalmente nos seguintes temas: missiologia, religião e antropologia, atuando principalmente nos seguintes temas: povos indígenas, comunidades indígenas, missão, missão entre povos indígenas e pastoral indigenista, missão urbana, teologia e cidadania, teologia pública, teologia da paz, educação teológica contextual, teologia e ecologia, teologia e interculturalidade. E-mail: rezwetsch@gmail.com
} 


\section{INTRODUÇÃO}

Em março de 1964 eu tinha 11 anos de idade e cursava o primeiro ano do que, na época, se chamava curso ginasial. Minha família passara por dificuldades financeiras, meu pai saíra de um período de grave enfermidade, em que quase veio a perder a vida, de modo que ele e minha mãe decidiram mudar de rumo. Meu pai vendeu a mercearia e voltou a trabalhar no serviço de terra da Cia. Varig, em Porto Alegre. Minha mãe voltou a ser dona de casa em período integral para cuidar de três filhos e duas filhas. Eu saí de uma escola comunitária evangélica em Porto Alegre e fui para a escola pública com meus irmãos, estudando num colégio estadual em Canoas, região metropolitana de Porto Alegre. Na escola pública concluí anos depois o curso científico, hoje ensino médio, então já morando em Curitiba, PR, no ano de 1970. Uma recordação inesquecível foi acompanhar pela TV a chegada do primeiro astronauta norte-americano à Lua em junho de 1969, acompanhado por meu pai. Inimaginável pouco tempo antes.

Não lembro quase nada de que vivíamos numa Ditadura. Lembro bem que em 1970 saí de casa com vários amigos pelas ruas do centro da capital paranaense para comemorarmos a vitória do Brasil na Copa do México. Mas ainda assim, algumas dúvidas pairavam em meu espírito porque fizera amizade com estudantes universitários que moravam na CEU - Casa do Estudante Universitário, em Curitiba, que eu passara a frequentar seguidamente porque alguns de meus amigos do grupo de jovens da Igreja nela moravam e vez por outra me contavam de suas dificuldades e "loucuras", como fugir da polícia no centro da cidade. Foi um desses amigos que me deu de presente um dos livros que li avidamente e que me marcou como aspirante ao estudo de teologia. Tratava-se de Resistência e submissão, do teólogo luterano alemão Dietrich Bonhoeffer, que continha uma seleção de suas cartas da prisão, escritas entre 1942 e 1945, traduzidas ao português pelo Reverendo anglicano Ernesto J. Bernhoeft, e que foram publicadas no Rio de Janeiro, em 1968, pela Editora Paz e Terra. O livro me marcou porque eu me deparei com um cristão radical que foi preso e enforcado pela Gestapo de Hitler justamente porque não abriu mão de sua fé cristã e a assumiu em oposição ao ditador alemão, com todas as consequências que disso poderia resultar. Bonhoeffer foi um dos que participou de um complô para assassinar Hitler em 1942, que teve frustrado seu objetivo, sendo seus principais organizadores (alguns de alta patente militar) sido presos 
ou enforcados. Bonhoeffer foi levado à forca em 09 de abril de 1945, pouco antes do término da $2^{\mathrm{a}}$ Guerra Mundial, por ordem explícita de Hitler.

Em março de 1971, cheguei a São Leopoldo, RS, para iniciar o curso de teologia, na Faculdade de Teologia da Igreja Evangélica de Confissão Luterana no Brasil - IECLB. Como todo estudante evangélico da época, vinha cheio de entusiasmo para me preparar para o ministério pastoral e a missão de propagar o evangelho de Cristo neste país. Mas chegava ainda muito ingênuo e sem clara consciência do que acontecia no Brasil. Só aos poucos fui me dando conta do que significava a repressão, a censura, a proibição das manifestações estudantis, o arbítrio, a ausência das liberdades democráticas, pelas quais começamos a nos debater nos anos seguintes. Nesse ínterim, já assimilando o duro aprendizado com meus companheiros e companheiras de centro acadêmico do que era fugir da polícia militar e seus cavalos, esquivar-se dos jatos d'água dos carros militares quando nas manifestações em Porto Alegre (imagine-se esta prática nos meses do inverno sulino) e até receber bordoadas nas pernas ao fugir dos policiais que nos perseguiam pelas ruas do centro. Seguidamente frequentamos o grande salão da Assembleia Legislativa do Rio Grande do Sul, em noites memoráveis, quando ouvíamos conferências críticas ao regime militar, como as de Fernando Henrique Cardoso, Dom Paulo Evaristo Arns, André Forster e outros intelectuais progressistas.

Em 1978, ainda antes de me mudar para a Amazônia, participei da luta pela libertação dos uruguaios Lilian Celiberti e Universindo Díaz, da luta pela libertação de Flávia Schilling e de Flávio Koutzii. Em nossa república Princípio da esperança ${ }^{1}$, escrevíamos à mão notícias, reflexões, protestos, cartas, palavras de ordem para divulgar em nossa faculdade num mural que recebeu o tortuoso nome de $O \mathrm{pau}$, pois tinha por finalidade explícita sentar o pau, criticar, debater, abrir a boca contra as injustiças onde quer que elas ocorressem. Nosso mural teve uma característica única: era escrito inteiramente à mão, com canetas hidrocor. Não aceitávamos recortes ou qualquer papel datilografado. E assim o fizemos até que o mural se esgotou, tempos depois.

Nunca fui preso ou interrogado. Em 1972 comecei estudos de ciências sociais na Unisinos - Universidade do Vale do Rio dos Sinos, ao lado do curso

\footnotetext{
1 Éramos quatro estudantes de teologia luteranos e moramos na vila Esperança, em São Leopoldo, RS: Olavo Nienow, Rolf Schünemann, Vítor Westhelle e eu. Nos anos de 1980, o sociólogo Olavo Nienow e pastor Otto Ramminger foram presos em Ji-Paraná, RO, junto com vários agricultores sem terra, por mais de um mês por apoiarem a luta pela terra de posseiros da região do município de Colorado do Oeste, RO. Seu processo durou mais de 20 anos, ao final do qual foram absolvidos por falta de provas.
} 
de teologia, e como membro do Centro Acadêmico do Centro 1 (Ciências Humanas), participei da criação de um jornaleco estudantil chamado, não por acaso, de Contracorrente. As primeiras edições nós datilografamos em folhas de stencil e reproduzíamos nos miemeógrafos a tinta, com ilustrações feitas por estudantes amigos do curso de arquitetura. Lembro que no primeiro número publicamos na última página o poema Estatutos do Homem, de Thiago de Mello. Para distribuirmos o jornal, montamos uma estratégia que consistia em um grupo de dois ou três entrar na sala de aula, distribuir o jornal e sair na corrida para não sermos pegos pela guarda da Universidade. Este tipo de ação era proibido na Unisinos, em 1972! E esta é uma universidade jesuítica até hoje.

Quando concluí o curso de teologia em 1977, ainda frequentei por dois semestres o curso de ciências sociais, mas não o completei, pois em 1978 após casar com uma colega da teologia, resolvemos assumir a causa indígena (com a qual já estávamos envolvidos fazia mais de dois anos) como concretização de nossas convicções e em solidariedade a esses povos. A IECLB nos enviou para um trabalho missionário com o povo Suruí/Paíter, em Cacoal, Rondônia, para onde nos mudamos em agosto de 1978. No final de 1979, seríamos expulsos da área por não seguirmos a cartilha da FUNAI e apoiarmos o movimento indígena. Acabamos nos mudando para o Acre, onde trabalhamos com o povo Kulina/Madihá por sete anos, numa pequena comunidade no alto Purus, fronteira do Brasil com o Peru. Antes disso, por dez meses em 1977 trabalhei como aprendiz de jornalista no Jornal Evangélico, período em que fiz uma matéria muito importante em minha trajetória. O jornal queria publicar algo sobre os atingidos pela hidrelétrica de Itaipu e me enviou ao oeste do Paraná por uma semana para ouvir pastores, trabalhadores rurais, peões de fazenda, boias-frias, lideranças políticas. Foi uma tarefa grande demais para um aprendiz, mas fiz o que pude. Algumas das fotos que tirei com uma extraordinária máquina Rolleiflex devem constar dos arquivos do jornal. Numa delas, registrei o rosto de uma menina boia-fria de uns 12 anos de idade com enxada na mão, no meio do roçado em que trabalhava. Aquele rosto triste, mas de olhos firmes ainda hoje brilha em minha memória.

Como jovem cristão evangélico, foi a duras penas que me dei conta do país em que vivia e do que significava viver sob uma ditadura que realizou, em fins de 1968, o golpe dentro do golpe, endurecendo ainda mais o regime, perseguindo, prendendo, torturando e assassinando sem dó nem piedade opositores do regime, intelectuais, operários, camponeses, estudantes, homens e 
mulheres que muitas vezes jamais ficaram sabendo das razões de suas prisões ou torturas. Li recentemente um livro de memórias de um filósofo, professor à época, que relata com muita sensibilidade e dor o drama vivido pelas pessoas que procuraram manter o direito de pensar diferente, de posicionar-se contra a corrente dominante, sofrendo por isto a prisão, a tortura e o peso do arbítrio, algo que instalou em suas almas, corpos e mentes uma ferida que - em muitos casos - jamais chegou a cicatrizar: Retrato calado, de Luiz Roberto Salinas Fortes (São Paulo: Cosac Naify, 2012), prefaciado por Marilena Chauí, amiga e colega de profissão. Salinas acabou por falecer em 04/o8/1987, vítima de um enfarte que o atingiu durante uma visita à casa de amigos ${ }^{2}$.

Em 1974 tive a oportunidade de realizar um período de intercâmbio de estudos, durante o qual vivi por um ano na cidade do Recife, estudando no ITER - Instituto de Teologia do Recife, cujo reitor era Dom Hélder Câmara. Como estudante luterano, fui acolhido de forma fraterna na casa do então Padre Reginaldo Veloso e seus companheiros de ministério, na periferia do Recife, Córrego do Genipapo, onde morei até dezembro. Foi um tempo de descobertas intenso. Comecei a descobrir um país que eu só conhecera por meio da literatura. E o que muito contribuiu foi o convite para trabalhar na ACR Animação dos Cristãos no Meio Rural, antiga Ação Católica Rural, junto com o Padre José Servat. Foi por meio da ACR que visitei a zona da mata, conheci o movimento dos cortadores de cana e me solidarizei com suas reivindicações. $\mathrm{O}$ estudo de teologia me proporcionou conhecer de perto a Arquidiocese de Olinda e Recife, seu Arcebispo Dom Hélder Câmara, a organização da ação pastoral e o pessoal leigo que realizava o trabalho da pastoral popular nos bairros e periferias, como - por exemplo - através do Encontro de irmãos. Foi quando passei a acompanhar de perto o que depois ficou conhecido como comunidades eclesiais de base. Fui aluno de Ivone Gebara, Valéria Rezende, Eduardo Hoornaert, Humberto Plummen, colega de debate de Biu Vicente, Raminho,

\footnotetext{
${ }^{2}$ Em seu livro, há a seguinte passagem que torna sua morte algo ainda mais trágico: “A passagem pelos subterrâneos do regime, o contato com o avesso do milagre eram, nestas condições, a ocasião para um aprendizado tão importante quanto inútil, pelo menos durante muitos anos. Mas, de qualquer maneira, experiência decisiva no interior da selvagem fenomenologia. Guinada. Depois dela, depois de termos ingressado no espaço da ficção oficial, passávamos para outra figura do espírito, para o delírio em cujos breus parecem comprometidas as fronteiras entre o imaginário e o real. Tudo teria então pura ficção? Tudo ficará por isso mesmo? A dor que continua doendo até hoje e que vai acabar por me matar se irrealiza, transmuda-se em simples 'ocorrência' equívoca, suscetível a uma infinidade de interpretações, de versões das mais arbitrárias, embora a dor que vai me matar continue doendo, bem presente no meu corpo, ferida aberta latejando na memória”. FORTES, Luiz Roberto Salinas, Retrato calado. $2^{\mathrm{a}}$ ed. São Paulo: Cosac Naify, 2012, p. 41s. Nos Posfácio, Antonio Candido, após recordar a dignidade angustiada de Salinas e a importância dessa obra para o próprio autor, escreveu o seguinte: "Luiz Roberto parecia haver-se finalmente conciliado consigo mesmo. Mas, ironicamente, a recompensa do longo esforço para se encontrar foi a morte” (p. 126).
} 
Vieira, Tereza e outros e outras. O Nordeste deixou de ser uma terra distante e impregnou meu ser com suas misérias, seus impasses históricos, sua música (ah, velho Gonzagão!), suas danças (ah, que saudades da ciranda, do frevo), seu povo alegre, criativo, cheio de uma esperança cativante. Tive o privilégio de acompanhar naquele ano a campanha política e ouvir comícios com o senador Marcos Freire e o jovem deputado Jarbas Vasconcelos. Minha vida recebeu mais um marco, este definitivo: antes e depois do Recife!

No que segue procuro alinhavar algumas informações e reflexões, a partir de vivências da época, focando na opção pela luta não-violenta como forma de combater a Ditadura civil-militar e lhe opor resistência ativa e inconformista. A experiência nela adquirida transcendeu o campo estritamente político e veio a se tornar uma maneira de encarar a vida, a sociedade, a história do nosso tempo. O aprendizado da não-violência do Mahatma Gandhi, de Martin Luther King Jr., de Dom Hélder Câmara veio a se tornar no Brasil o que nos anos de 1970 se chamou firmeza-permanente. Com este nome conseguimos assumir os ideais da não-violência ativa, dar uma resposta aos grupos de oposição política que haviam optado pela luta armada, bem como buscar caminhos que nos aproximassem do povo, das classes oprimidas, dos povos indígenas, dos quilombolas, dos moradores da floresta, o que nos exigiu refazer o caminho da teologia, agora desde a caminhada de base, em busca da libertação: aprendemos nela a fazer teologia da libertação e isto nos acompanha até os dias de hoje, evidentemente com novas exigências e outros caminhos para manter a coerência com a opção e a lucidez da visão e do imaginário libertador em que nos jogamos com a fé no evangelho, o amor e paixão pelos pobres e vulneráveis. A defesa da liberdade, dos direitos humanos e da dignidade da vida se tornou mais que um princípio de ação. Foi a forma concreta de compreender e realizar o que entendemos - desde então - ser a mensagem evangélica do Cristo Crucificado e Ressurreto numa história que, de resto, é e sempre será ambígua, incongruente e desafiadora.

1 MAIS QUE AMBIGUIDADE: o apoio das igrejas cristãs ao Golpe civil-militar e o início da resistência

Desde as primeiras horas do Golpe de 1964 ou a quartelada, como qualificou o cronista Carlos Heitor Cony corajosamente no seu livro $O$ ato e o fato, nos primeiros dias de abril de 1964, as opiniões nas igrejas cristãs se dividiram, a favor e contra o golpe que derrubou João Goulart, um Presidente civil democraticamente eleito, instaurando a repressão aos movimentos sociais, 
a perseguição aos opositores, a prisão, a tortura e a intolerância geral. Com segurança, porém, pode-se afirmar que o primeiro grupo foi majoritário e orientou a ação pastoral das igrejas desde então e por praticamente todos os vinte anos do regime instituído à força e autodenominado "revolução de 64", que desde 10 de abril daquele ano ao baixar o Ato Institucional $\mathrm{n}^{0} 1$ optou pela "tirania", como escreveu Cony em crônica publicada no Correio da Manhã de 11/04/1964. No dia 14 de abril, Cony voltou a escrever. Se o Alto Comando Militar chama o seu movimento de revolução, que assim seja, mas fique claro de que é uma "revolução de caranguejos", uma revolução que anda para trás, que ignora a época e a marcha da história. De fato, ela instituiu o obscurantismo que cerceou a liberdade, a participação política, a criatividade artística, comprometendo uma geração inteira que viveu e cresceu sob uma cortina de fumaça e num ambiente de ufanismo vazio alicerçado num patriotismo tacanho e eivado de preconceitos. Para Cony, que se tornou uma espécie de "voz pública" da inconformidade com o tipo de governo que começava a se instalar no país, o que aconteceu em 1964 foi um "recuo humilhante" que desmoralizou o país perante o mundo, destruindo o que a nação tinha de melhor: a vergonha (crônica de 14/04/1964).

Pouco a pouco o regime instituiu na sociedade algo que a dividiu moralmente: o dedodurismo, a prática da acusação sem provas e que levou milhares de concidadãos à prisão por simplesmente exerceram seu direito de pensar por si mesmos ou de discordar das autoridades. Infelizmente, isto aconteceu inclusive nas igrejas, como escreveu o editor Ênio Silveira no prefácio ao livro de Cony: "As prisões se encheram, a violência campeou solta. Senhoras altamente católicas e indubitavelmente avós viram-se possuídas do mesmo furor sanguinário das tricoteuses francesas. As denúncias e delações substituíram a biriba como passatempo familiar, e houve padres que se voltaram contra outros padres do púlpito de suas igrejas, irmãos que se voltaram contra irmãos. Institucionalizava-se o dedodurismo como virtude cívica. Um silêncio de urubus em cima da carniça desabou, sólido e opressivo, sobre o País" 3.

Mas isto também aconteceu em igrejas evangélicas como no caso da Igreja Presbiteriana do Brasil - IPB, que transformou a Universidade Mackenzie da Rua Maria Antônia em São Paulo num centro da reação direitista. Um caso exemplar foi o que ocorreu na luta entre facções do Movimento Estudantil em

3 CONY, Carlos Heitor. O ato e o fato. Crônicas políticas. Rio de Janeiro: Civilização Brasileira, 1964, Prefácio do Editor Ênio Silveira. 
1968, quando a Universidade presbiteriana se tornou a sede do fascista CCCComando de Caça aos Comunistas, como relatou em detalhes Zuenir Ventura4.

$\mathrm{Na}$ Igreja Metodista do Brasil também houve quem assumisse voluntariamente a delação de irmãos de fé, por causa de suas opções politicas, como recentemente denunciado pelo cientista social Anivaldo Padilha, na época responsável pelo Departamento de Jovens da igreja, e que motivado por denúncia de um pastor e de um bispo da própria igreja, foi preso, torturado e depois obrigado a se exilar para sobreviver à perseguição. Ao relatar parte do seu sofrimento, recentemente, Padilha conta que ao sair da prisão, com o apoio do Conselho Mundial de Igrejas e das redes ecumênicas internacionais, conseguiu chegar clandestinamente no Uruguai, dali foi à Argentina, ao Chile e finalmente para os EUA, onde conseguiu reconstruir aos poucos sua vida. No Brasil, ficara uma companheira grávida, que deu à luz um menino que se chamou Alexandre Padilha, ex-ministro da saúde no governo de Dilma Rousseff. O pai só foi conhecê-lo aos oito anos após retornar ao Brasil, um encontro que marcou para sempre a ambos. Além dessa ruptura de laços, por seis anos Padilha tinha pesadelos constantes provocados pelas sessões de tortura. Os torturadores, narra,

continuavam dentro de mim a me torturar. Eu tinha de vencê-los. A luta foi longa até que percebi [...] que o caminho a seguir era o do perdão. Ao perdoá-los, consegui vencê-los. O perdão significou para mim um processo terapêutico. Há momentos que o perdão é mais importante para quem perdoa do que para quem é perdoado, mas isso no nível das relações interpessoais. Isso não significa compactuar com a impunidade. Os crimes cometidos não foram apenas contra mim. Foram contra a sociedade brasileira e a sociedade tem o direito de investigá-los e punir os responsáveis diretos e indiretos. 5

Padilha complementa argumentando que a impunidade contribui para que a tortura ainda seja praticada em larga escala nas delegacias e prisões brasileiras e para que outras formas de intolerância se fortaleçam e multipliquem país afora. Talvez se possa afirmar ainda que a expressiva recorrência de linchamentos no Brasil seja o outro lado dessa moeda maldita, que revela uma completa descrença no sistema judicial do país.

Em 1969, a Igreja Evangélica de Confissão Luterana no Brasil se preparava para receber no ano seguinte a Assembleia da Federação Luterana Mundial -

4 VENTURA, Zuenir. 1968 - O ano que não terminou. 12. Ed. Rio de Janeiro: Nova Fronteira, 1988, p. 221ss.

5 PADILHA, Anivaldo Pereira. Reflexões sobre medidas de verdade: do Brasil Nunca Mais a uma comissão da verdade. In: Caminhando. São Bernardo do Campo, v. 16, n. 1, p. 169, jan/jul 2011. 
FLM, evento que seria realizado em Porto Alegre, RS, e que reúne representantes de todas as igrejas luteranas do mundo a cada oito anos. Denúncias de perseguições a opositores do regime e de torturas nas prisões da Ditadura, fizeram com que Igrejas Luteranas da Europa pressionassem a IECLB para que se posicionasse publicamente sobre estes fatos e não convidasse o general Presidente Médici para a abertura do evento. Este convite foi posteriormente desfeito, devido às críticas feitas à direção da Igreja, mas não foi suficiente para evitar a transferência do evento. A direção da IECLB na época reagiu fortemente contra as denúncias afirmando que não havia tortura no Brasil, revelando um desconhecimento comprometedor do que se passava na realidade brasileira. Isto motivou que um grupo de pastores progressistas enviasse a São Paulo - clandestinamente - dois colegas para colher informações seguras do que se passava nos porões da Ditadura. A repressão era tão feroz que estes pastores - hospedados durante poucos dias num hotel simples próximo à Estação da Luz - montaram seu Relatório com todos os dados coletados, decoraram seu conteúdo para em seguida o jogarem na privada, antes de retornarem ao sul de ônibus, sem qualquer anotação mais comprometedora para a eventualidade de um cerco policial, algo corriqueiro na época. Na chegada a Porto Alegre, pacientemente reescreveram o texto para apresentá-lo ao Pastor Presidente da IECLB, que só então parece ter-se compenetrado do que acontecia clandestinamente nas prisões do país. Recentemente soube-se que o tal Relatório entregue à direção da IECLB não consta dos arquivos oficiais e dele não se tem nenhuma cópia! Apenas o registro oral das pessoas diretamente implicadas no fato.

Em vista desses ocorridos, a FLM decidiu suspender a Assembleia em Porto Alegre, transferindo-a em julho 1970 para Evian, pequena cidade francesa não muito distante de Genebra, seis semanas antes da abertura, o que dá a dimensão do ocorrido . Isto causou muito desgosto para a igreja brasileira e as comunidades diretamente envolvidas na longa preparação do evento, embora o grupo progressista minoritário a tenha apoiado ${ }^{6}$. Rolf Schünemann em seu estudo analisa os bastidores da Assembleia e repercute o fato no contexto interno da IECLB:

Assim os leigos de classe média não tinham compreensão para as críticas que vinham do exterior e advogavam uma separação de Igreja e política. Todo o triunfalismo eclesiástico e nacionalista sofreu um grande revés. Depois que os ânimos serenaram, uma nova geração procurou afirmar-se. Os setores que

${ }^{6}$ SCHUENEMANN, Rolf. Do gueto à participação. São Leopoldo: Sinodal, EST/IEPG, 1992, p. 81-95. 
permaneceram marginais durante a década de sessenta começaram, no início da década de setenta, a conquistar os seus espaços. Remanescentes do Movimento Estudantil, Juventude Evangélica e pastores jovens tiveram a seu favor a própria história brasileira, que lhes vinha confirmar as teses que anteriormente eram colocadas à margem. A crítica ao autoritarismo e desenvolvimento confirmou-se na medida em que o próprio regime autoritário era desmascarado e o próprio desenvolvimentismo apresentava cada vez mais contradições. A transferência da V Assembleia Geral da FLM operou como uma terapia de choque, abrindo as portas para um posicionamento sócio-político mais crítico e participativo. $\mathrm{O}$ adesismo puro e simples foi questionado.7

Um fato demonstra o clima em que se vivia naqueles anos. $\mathrm{O}$ estudante de teologia Werner Fuchs e o estudante de economia Erich Ramminger foram escolhidos para participar do encontro preparatório de jovens luteranos, na cidade do México. Ambos solicitaram uma posição do Pastor Presidente da IECLB e do Conselho Diretor, que não dava resposta. Os dois decidiram viajar, pois já tinham recebido as passagens ${ }^{8}$. Quando no México, receberam um telegrama do Brasil por meio do qual o Conselho Diretor havia decidido não enviar representante nenhum a Evian e que os dois deveriam retornar ao Brasil. Os dois solicitaram passagem de volta do México ao Brasil, mas como em Porto Alegre (sede da Igreja) ninguém lhes atendeu, seguiram para a França. Na abertura da Assembleia, se encontraram com os pastores Gottschald e Kunert, além da jornalista brasileira Sibyla Baeske. Os jovens haviam decidido levantar tarjas pretas quando fosse mencionado o "progresso" brasileiro. Os dois jovens ficaram nas galerias e protestaram. Atrás deles estavam postados outros jornalistas brasileiros. No dia seguinte, no jornal Correio do Povo, de Porto Alegre estava a manchete: Dois jovens brasileiros participaram do protesto. Esta manifestação, num momento tenso como o que se vivia no Brasil (após AI-5), foi o principal motivo - segundo Fuchs - para que ele sofresse uma espécie de inquisição na Igreja e uma permanente má vontade em relação a sua pessoa, mesmo depois de ter ingressado no ministério pastoral.

\footnotetext{
7 SCHÜNEMANN, Rolf, 1992, p. 95. O "Manifesto de Curitiba" que a IECLB lançou publicamente em outubro de 1970, como documento do Concílio Geral da Igreja, tendo sido entregue oficialmente ao Presidente Médici em 05/11/1970, é um dos resultados desse "choque" de realidade. Embora pareça ainda conservador hoje, o documento - possivelmente a primeira manifestação eclesiástica crítica ao regime civil-militar, e fruto de uma difícil articulação da minoria crítica - destaca temas fundamentais naquela época em matéria de política eclesiástica, a contragosto da direção de uma parte dos conciliares: a) a separação entre igreja e estado, sendo a igreja uma atalaia (vigia) da consciência da Nação (Ezequiel 33.7); b) a importância dos direitos humanos para uma sociedade democrática; c) a cooperação da igreja com o estado se dá de maneira que as pessoas sejam beneficiadas, eliminando-se as causas das injustiças; d) o diálogo com o estado se deve dar sem demagogia e sempre advogando em prol das pessoas que sofrem (p. 102). O documento foi divulgado amplamente só no dia $15 / 11 / 1970$, no dia de eleições, para evitar exploração indevida.

${ }^{8}$ Em carta pessoal de 01/05/2014, Werner Fuchs narra o ocorrido e anota sobre a Copa do Mundo: "Foi lá que assisti pelo TV ao jogo do Tri, torcendo contra. Eu estava a cerca de mil metros do estádio. Ramminger havia conseguido ingresso e festejou a vitória”.
} 
É este mesmo personagem que, nos anos 1980, como pastor no oeste do Paraná, participa da organização do movimento de pequenos agricultores e da Comissão Pastoral da Terra, órgão vinculado à CNBB. Nesse época também integra o Movimento Justiça e Terra, participa da luta dos atingidos pela barragem de Itaipu e do MASTRO, precursor do MST. Desde 1985 residia em Curitiba e foi ali que denunciou, em praça pública, no dia 25/07/1986, Dia do Colono, o caso do campo Marechal Hermes, de Papanduva, SC. Curitiba é a sede da $5^{\text {a }}$ Região Militar, que usa até hoje aquele campo para treinamento militar. Os agricultores que sofreram com a presença dos militares vinham a Curitiba para pedir ajuda à CPT. Devido à denúncia, Werner Fuchs foi submetido a Inquérito Penal Militar e condenado em maio de 1987 por "difamação das Forças Armadas”. Após passar por várias instâncias, ele foi absolvido pelo Supremo Tribunal Federal, em agosto de 1989. A sentença era de seis meses transformados em condicional de 2 anos. Fuchs tinha de se apresentar ao juiz sempre que pretendia viajar, inclusive depois de residir em São Leopoldo, onde atuou como professor na Escola Superior de Teologia. Ele se considera o último brasileiro condenado pelo regime militar, quando a Ditadura já havia acabado. Em carta pessoal, de 01/05/2014, ele comenta:

Meu caso serviu para 2 coisas: 1) foram arquivados 2 processos contra agricultores vítimas de arbitrariedades dos comandantes do campo de Papanduva (em suma, a área fora desapropriada e até hoje os proprietários e seus herdeiros não foram cabalmente indenizados); b) as forças que lutaram pela revogação da Lei de Segurança Nacional se esqueceram do Código Penal Militar, que permitia processar civis em conflito com as Forças Armadas.

Fuchs foi inocentado, mas durante muito tempo carregou a carga de uma pena injustamente a ele atribuída. Ainda assim, seu compromisso com a justiça e a luta dos agricultores sem terra nunca esmoreceu.

Outro caso que merece registro é o que envolveu o intelectual Paulo S. Wright, membro da Igreja Presbiteriana do Brasil - IPB, irmão do Rev. James (Jaime) Wright, este mais tarde responsável, junto à Arquidiocese de São Paulo, com Dom Paulo Evaristo Arns, pelo Projeto Brasil Nunca Mais. Auspiciado pelo Conselho Mundial de Igrejas (CMI), o Projeto possibilitou a um grupo de advogados e investigadores brasileiros, inspirados e motivados pela advogada brasileira Eny Raimundo Moreira e dirigidos por Paulo Vanucchi, a partir de 1979, consultar e clandestinamente fotocopiar uma importante e massiva gama de documentos nos arquivos dos tribunais militares de processos contra presos 
políticos, comprovando para o mundo, através de sua remessa clandestina ao CMI, em Genebra, prisão, tortura e assassinato de presos políticos pelas forças de repressão da Ditadura brasileira. A documentação pertinente ao desenvolvimento do projeto ficou guardada nos arquivos do CMI, enquanto as fotocópias dos processos, quase um milhão de páginas, foram remetidas ao Center for Research Libraries em Chicago, onde, microfichados, foram preservados. Em junho de 2011, em ato público na cidade de São Paulo, o Secretário Geral do CMI, o pastor norueguês Olav Fykse Tveit e o então Moderador do Comitê Central do CMI, pastor brasileiro Walter Altmann, repatriaram toda a documentação, fazendo sua entrega à Procuradoria Geral da República, para fins de preservação no país e digitalização do acervo. Esta tarefa ficou concluída em 2013, quando em novo ato público foi lançado o portal do projeto Brasil Nunca Mais@Digital.

Voltando a Paulo S. Wright, ele teve seu mandato como deputado estadual pelo PSP cassado em SC, mas não deixou de atuar politicamente, passando a apoiar a causa dos pescadores, formando núcleos pela costa do estado, de São Francisco a Araranguá, acabando por juntar quatro mil associados na FECOPESCA, Federação das Cooperativas de Pescadores. Ao inaugurar uma estrutura organizativa inédita, despertou a ira dos grupos econômicos que exploravam o trabalho dos pescadores, principalmente os atravessadores de peixe9. Mais tarde, Paulo S. Wright foi preso e se tornou um dos muitos desaparecidos políticos (1973), cujo corpo jamais foi encontrado. Seu irmão Jaime Wright lutou até morrer para obter essas informações, trabalhou com afinco no Projeto Brasil Nunca Mais, reuniu dados sobre centenas de presos políticos e desaparecidos, mas nunca encontrou os restos mortais do irmão ${ }^{10}$. Até a presente data, a família aguarda explicações convincentes do governo brasileiro. Mais um caso - entre muitos - a ser esclarecido pela Comissão Nacional da Verdade, criada apenas em 2011 e instituída em maio de 2012, por iniciativa do governo da Presidenta Dilma Rousseff ${ }^{11}$.

\footnotetext{
9 ALVES, Márcio M. O Cristo do povo. Rio de janeiro: Sabiá, 1968, p. 118 e seguintes.

10 BRASIL NUNCA MAIS. Prefácio de Dom Paulo Evaristo Arns. 13. ed. Petrópolis: Vozes, 1986, p. 265 e 293. Paulo S. Wright foi um dos fundadores da Ação Popular - AP. Foi sequestrado pelo II Exército, em setembro de 1973, e levado ao DOI-CODI, na Rua Tutóia, em São Paulo. Foi visto nas dependências internas do DOI-CODI pela enfermeira Maria Diva de Faria, em cuja residência Paulo estivera hospedado no dia de seu desaparecimento. Para conhecer mais da vida de Paulo S. Wright, vale conferir o filme PSWUma crônica subversiva, com a participação de Antônio Fagundes (www.repas.org.br/downloads/pormuitas-maos.pdf ) .

${ }^{11}$ Em relato feito à Comissão Nacional da Verdade, em fins de março de 2014, o coronel reformado do Exército, Paulo Malhães, 77 anos, confirmou sua participação em torturas, mortes e ocultação de cadáver no regime militar. Uma informação deveras importante diz respeito ao desparecido corpo do deputado Rubens Paiva. Em depoimento anterior à Comissão Estadual da Verdade do Rio de Janeiro, o militar declarara que sumira com o corpo do deputado em 1971, contudo voltou atrás nesse particular ao depor na
} 
Hoje sabemos por documentos colhidos nos EUA que o golpe teve participação direta da embaixada norte-americana e dos serviços do embaixador Lincoln Gordon. Também está comprovada a participação direta de empresários e empresas no financiamento do golpe e nas ações dos órgãos de repressão posteriormente ${ }^{12}$. Vigorava na época a Guerra Fria que dividiu o mundo entre EUA e União Soviética - URSS, sendo que o grande perigo visto pelos militares e ampla gama de forças da ordem dominante (empresas, grande imprensa, setores das classes médias) era a possível, remota - e nunca provada possibilidade da implantação do comunismo no Brasil, após a vitória das forças guerrilheiras de Fidel Castro na pequena Ilha de Cuba, no Caribe, em janeiro de 1959. Foram estes setores que, em conluio com os interesses dos EUA, articularam, financiaram e realizaram o golpe civil-militar de $1964^{13}$.

\section{A CONTRIBUiÇão do MOVIMENTO DA NÃO-VIOLÊNCIA ATIVA NA RESISTÊNCIA À DITADURA $^{14}$}

O conceito de não-violência ativa tem uma de suas origens nas ideias e nas práticas do líder indiano Mahatma Gandhi, o grande libertador da Índia do domínio colonial inglês. Nas Cartas de Ashram, Gandhi escreveu: "Existem duas maneiras de mudar uma pessoa, dois tipos de 'terremoto' que vão transformar a consciência. O medo ou então a emoção. A não-violência repousa principalmente sobre o poder de comover”. Ao explicar este conceito, Dom Paulo Evaristo Arns escreveu:

Comissão Nacional da Verdade dias depois, atitude que suscitou a suspeição de que tivesse sofrido pressões após seu primeiro depoimento. Estranhamente, Malhães foi assassinado no dia 25/04/2014, em sua casa em Nova Iguaçu. Segundo a polícia, seu corpo apresentava sinais de asfixia. O jornalista Nilson Mariano escreveu em sua coluna: "Os três homens que mataram o coronel [...] eliminaram a testemunha que poderia detalhar como funcionava o aparato repressivo. Malhães sabia quem eram os outros verdugos e, o mais grave, quem eram os mandantes de crimes até hoje insolúveis. Poderia ajudar a decifrar um dos maiores enigmas dos Anos de Chumbo: onde estão os restos mortais do ex-deputado Rubens Paiva, torturado pelo DOI-CODI do Rio de Janeiro, em 1971". É bem possível que se trate de "queima de arquivo", mais uma testemunha silenciada. Zero Hora, p. 8, 26/04/2014.

12 TAVARES, Flávio.1964. O golpe. Porto Alegre: L\&PM, 2014. Na terceira parte deste livro, o autor publica documentos secretos irrefutáveis do governo norte-americano, consultados na biblioteca Lyndon B. Johnson, em Austin, Texas. Outros foram encontrados na biblioteca e museu John F. Kennedy, de Boston, Massuchusetts. Tavares conta também que tais documentos somente foram liberados, gradativamente, a partir de 1975, a partir de cópias autênticas fornecidas pelo National Security Archives (NARA), da Universidade George Washington, de Washington, D.C.

13 Nos últimos anos têm sido escritos muitos livros que trazem análises nem sempre convergentes quanto às raízes e fundamentos históricos da ditadura brasileira e suas relações com a sociedade. O debate está na ordem do dia e exige o cuidado e a competência para aclarar o passado sombrio do regime militar e a árdua luta pela restauração democrática. Entre outros, cf. REIS, Daniel Aarão. Ditadura e democracia no Brasil. Do golpe de 1964 à Constituição de 1988. Rio de Janeiro: Zahar, 2014.

14 Para os dois próximos tópicos, ver meu artigo : Da não-violência ativa ou firmeza-permanente à educação para a paz. In: Protestantismo em revista. São Leopoldo, v. 22, p. 2-12, maio-agosto 2010. 
A Não-Violência tem, como codificação imprescindível, o poder de comover. É uma repressão consciente e deliberada do impulso de vingança. É o controle espiritual que comove e purifica o homem oprimido e o opressor. O coração mais endurecido e a ignorância mais grosseira desaparecem diante do sol do sofrimento paciente e sem maldade. A fibra mais dura não subsiste ao fogo do amor. Se não fundir será porque o fogo não é bastante forte. ${ }^{15}$

Houve quem, na resistência ao arbítrio, à prepotência e à repressão desmedida optasse por uma ação não-violenta, que nem sempre foi bem compreendida na esquerda. Mesmo Gandhi sempre reconheceu o direito à violência como último recurso diante da tirania. Mas no caso brasileiro, esta opção caracterizou-se como particularmente ilusória, e em certos momentos, até suicida. De qualquer forma, sejam quais forem os argumentos, nada pode justificar as formas de repressão que o Estado desenvolveu para suprimir qualquer tentativa de oposição, legal ou clandestina. Afinal, o que tivemos foi não apenas um regime de exceção, mas um governo ilegítimo e tirânico.

Um caso paradigmático, do ponto de vista militar, é o Caso Para-sar. Tratase de um dos mais sinistros planos terroristas da história contemporânea no Brasil. Seu responsável foi o brigadeiro João Paulo Burnier, que respondia em 1968 pela chefia de gabinete do Ministro da Aeronáutica. Pelo plano várias personalidades políticas incômodas para o regime seriam sequestradas e lançadas ao mar, a 40 quilômetros da costa, um serviço a ser realizado por um grupo de elite dos paraquedistas. Entre outros visados, constavam Carlos Lacerda, Jânio Quadros, Juscelino Kubitschek, Dom Hélder Câmara, o general Olympio Mourão Filho. Haveria ainda pequenos incidentes como colocação de explosivos em locais de grande circulação e, como clímax, a explosão do gasômetro e de Ribeirão das Lajes, comandadas por controle remoto. Esta loucura só não veio a se concretizar porque um honrado capitão paraquedista, Sérgio Ribeiro Miranda de Carvalho, impediu sua execução, junto com a insurgência de outros cabos e sargentos. O capitão Sérgio foi punido e transferido para Recife, julgado e absolvido pelo Supremo Tribunal Militar, reformado pela Junta Militar em setembro de 1969. Poderia ter sido beneficiado pela anistia, mas a recusou com uma justificativa lapidar: "Anistia-se a quem cometeu alguma falta. Eu não posso ser anistiado pelo crime que evitei”. Em 1974 o brigadeiro Eduardo Gomes escreveu longa carta ao então Presidente Ernesto Geisel, na qual historia o episódio e solicita a reparação da "imensa

15 CARDEAL ARNS, Dom Paulo Evaristo. A firmeza-permanente: a força da não-violência. São Paulo: Loyola/Veja, 1977, p. 17. 
injustiça", pois ele sentia-se "pessoalmente atingido pelo que foi feito contra este digno oficial"16.

Voltando à não-violência, um dos primeiros testes de utilização da nãoviolência como instrumento de luta social no Brasil aconteceu na greve dos operários da Fábrica de Cimento Perus, do Grupo Abdalla, em Perus, SP, que iniciou em 1962 e teve como um dos líderes João Breno Pinto, apoiado pelo advogado sindicalista Mário Carvalho de Jesus. O Dr. Mário, como era conhecido, narrou como a longa luta dos trabalhadores só veio a triunfar 12 anos depois, em 1974, com o confisco da fábrica para pagar os salários atrasados dos grevistas e acabar com a poluição provocada na cidade de Perus ${ }^{17}$.

Mário Carvalho de Jesus foi um dos principais intelectuais da época que adotou na prática da luta social a não-violência ativa. Consultando o material publicado a respeito, penso que seja dele a releitura que se fez no Brasil dessa ferramenta de luta e que aqui foi rebatizada então como a expressão firmezapermanente. Sobre a longa greve dos trabalhadores da Perus, ele escreveu um depoimento esclarecedor:

Estamos convencidos de que a ação individual ou coletiva que respeita a pessoa humana, pelo exercício da não violência ou firmeza-permanente, pode alcançar parcialmente seus objetivos. Para isso precisamos estudar as leis, debater os casos, formar grupos de reflexão, de sustentação. Os abaixo-assinados, reuniões, assembleias sindicais são valiosos instrumentos para a consecução dos objetivos claros, limitados, deixando sempre uma saída digna para o empregador ou adversário. Naturalmente, mesmo agindo assim, corremos o risco de sermos convocados pela autoridade policial. Aí a gente vai e, sem medo, esclarece a autoridade sobre os fatos. Pode-se ficar lá um pouco mais do que o necessário, mas deixando a delegacia a gente continua na firmeza-permanentemente, em busca da justiça, cuja plenitude jamais conheceremos neste mundo. [...] $\mathrm{O}$ importante não é a gente ser valente ou violento de vez em quando, mas firme o tempo todo, a vida toda, em todas as atitudes, quer na família, na fábrica ou na sociedade. Ser firme não quer dizer ser o dono da verdade, mas estar disposto a descobrir a verdade para a realização da justiça para o homem todo e todos os homens. ${ }^{18}$

Um belo e dramático exemplo dessa atitude foi dada pelo grande jurista brasileiro Sobral Pinto. Após a edição do Ato Institucional no 5 , de 13/12/1968, o advogado estava hospedado num hotel de Goiânia, onde iria participar de uma

16 VENTURA, 1988, p. 209-219. Ventura informa que em 1988 em depoimento para o seu livro o exministro da Aeronáutica Márcio de Souza Mello minimizou o episódio, praticamente acusando o capitão pelo sinistro e frustrado plano. E sua justificativa é típica de quem está acostumado a hierarquizar o mundo, até mesmo o valor das palavras: "É a palavra de cabos e sargentos contra a palavra de oficiais". O nome do capitão Sérgio jamais deveria ser esquecido ao contar-se a história da Ditadura civil-militar de 1964.

17 CARDEAL ARNS, 1977, p. 39-90.

18 CARDEAL ARNS, 1977, p. 88s. 
solenidade de formatura da qual era paraninfo. Sobral repousava quando, de repente, a porta do quarto foi praticamente arrombada e um major e mais seis homens invadem o recinto para informar ao cidadão que, por ordem do Presidente Costa e Silva, ele deveria acompanhá-los. Do alto de seus 75 anos e com uma vida dedicada à justiça e ao país, Sobral Pinto respondeu ao assalto: "Meu amigo, o marechal Costa e Silva pode dar ordens ao senhor. Ele é marechal, o senhor major. Mas eu sou paisano, sou civil. O presidente da República não manda no cidadão. Se esta é a ordem, então o senhor pode se retirar porque eu não vou”. Espantado, o major gritou: “O senhor está preso!”, ao que o ancião respondeu: "Preso coisa nenhuma!" O major não teve dúvida, deu ordens para que o prendessem, arrastando-o até o elevador e pelo saguão do hotel. Comenta Zuenir Ventura, que relatou o fato: "Ao comandar aquele sequestro, o major certamente aprendeu que a bravura cívica podia ter 75 anos, pesar 67 quilos e andar de pijama e chinelo. A mesma lição seria aprendida pelo coronel comandante do quartel para onde Sobral foi arrastado”. Diante de uma pergunta insólita em se tratando daquele homem, que lhe inquiriu se era patriota, Sobral respondeu: "O senhor engula o que está dizendo! Eu sou patriota, o senhor não. O senhor vive à custa do Estado, eu não”. No quarto dia da sua prisão, na hora de dar seu depoimento, ele foi inflexível: "Não dou. É um desaforo que o Exército, depois de ter-me imposto esta humilhação, ainda tenha a petulância de querer devassar minha consciência. Em hipótese nenhuma! Eu não declaro nada”. O hábil coronel somente conseguiu obter algo do velho professor de direito ao perguntar se ele concordaria em escrever o que acabara de dizer. Proposta aceita, Sobral impôs como condição receber uma cópia do texto, completando: "Quando eu sair, quero escrever uma carta a esse ditador que está fingindo que é presidente da República [no caso, o marechal Costa e Silva]. Eu quero terminar a carta com esta declaração"19. Este fato ensina o que significou a luta do direito e da justiça contra a força e o arbítrio naqueles anos obscuros. Os milhares de estudantes que foram às ruas naquele ano de $1968 \mathrm{em}$ gigantescas passeatas no Rio de Janeiro, e que imaginavam ter a força para derrubar a ditadura demonstrando bravura e insubordinação, embalados em muita ilusão, por isto mesmo, atiçando os donos do poder e provocando o endurecimento do regime, encontram nesse senhor de espírito libertário um símbolo do que significa exercer cidadania e honradez, mesmo numa situação extrema e perigosa.

19 VENTURA, 1988, p. 296-299. 
Quando finalmente foi libertado, Sobral Pinto não deixou por menos. $\mathrm{O}$ tenente que lhe trouxe as roupas, disse-lhe: "Verifique que nos bolsos do seu colete tem dinheiro, o senhor faça o obséquio de contar para ver se falta alguma coisa". Resposta: "Não vou examinar coisa nenhuma. Os senhores são brutais e violentos, mas não são ladrões. O dinheiro deve estar aí”.

\section{NÃO-VIOLÊNCIA ATIVA OU FIRMEZA-PERMANENTE: UM CAMINHO PARA A PARTICIPAÇÃO CRISTÃ E A FORMAÇÃO DE CONSCIÊNCIA CRÍTICA ${ }^{20}$}

Mário Carvalho de Jesus foi dirigente por muitos anos da Frente Nacional do Trabalho, uma organização de apoio aos trabalhadores e sindicatos de trabalhadores no Brasil, associação civil criada em 1960. É ele que apresenta as raízes históricas da não-violência no Brasil, remontando aos grupos da Ação Católica (1940), em especial aos ramos da JOC e JUC, de onde também são oriundos muitos militantes de partidos clandestinos que vieram mais tarde a optar pela luta armada (por ex. a AP). Com a experiência da greve da Perus, Mário Carvalho de Jesus afirma que a característica de suas atitudes era precisamente a de firmeza e pacificação. Ele escreveu:

Nós não entendemos bem porque 'não-violência' nos parecia uma expressão pobre para uma atitude que exigia muita coragem. Foi então que Jean Goss (do Movimento Internacional de Reconciliação) acrescentou a palavra 'ativa': 'nãoviolência ativa'. Atualmente, desde 1973, vimos usando a expressão 'firmezapermanente' para identificar a não-violência. ${ }^{21}$

No artigo que escreveu nesse livro, Jesus apresenta os princípios que regem a ação não-violenta e seu potencial de transformação, justamente porque nela está embutido um profundo e leal respeito pelos adversários. Para ele, um dos primeiros objetivos da ação não-violenta é a aplicação das leis que estão em consonância com a Declaração Universal dos Direitos Humanos. ${ }^{22}$

Sua conclusão sobre a eficácia dessa opção de luta é a seguinte:

A eficácia da não-violência ativa, ou firmeza-permanente, é um teste para todo o cristianismo, todas as Igrejas, todas as religiões, todos os homens de boa vontade, ainda que não pratiquem religião, mas que creiam na dignidade do homem. ${ }^{23}$

\footnotetext{
${ }^{20}$ Uma das pesquisas mais completas sobre a não-violência e a educação para a paz foi a tese do monge beneditino: GUIMARÃES, Marcelo Rezende. Educação para a paz: sentidos e dilemas. Caxias do Sul: Educs, 2005.
}

\footnotetext{
${ }^{21}$ CARDEAL ARNS, 1977, p. 92.

${ }^{22}$ CARDEAL ARNS, 1977, p. 103-106.

23 CARDEAL ARNS, 1977, p. 106.
} 
Revelando a perspectiva ecumênica da não-violência ativa, que aliás contribuiu para que grupos de firmeza-permanente e de luta por paz e justiça se formassem país afora em muitas comunidades de fé, colaborando ainda para a criação dos importantes Centros de Defesa dos Direitos Humanos, ainda hoje em franca atividade, Mário Carvalho de Jesus escreveu:

O movimento ecumênico e humanitário se desenvolve na defesa dos direitos humanos. A Igreja Cristã tenta, humildemente, com altos e baixos, dar sua contribuição e apoiar a luta que se vale de meios puros, respeitando a pessoa humana, na busca da justiça. Nós fazemos parte dessa comunidade e estamos nos esforçando para ficarmos fieis à palavra do Bom Pastor. ${ }^{24}$

Não foram muitos os teólogos que se engajaram no movimento de firmezapermanente naqueles anos. Alguns apoiaram a resistência e colaboraram para salvar muitas pessoas perseguidas ajudando-as a saírem clandestinamente do Brasil. Frei Betto e frades dominicanos são um exemplo conhecido ${ }^{25}$. As cartas da prisão de Frei Betto dão conta do que significou para muitos cristãos a experiência da prisão e a convivência com companheiros/as de infortúnio que, mesmo não partilhando da fé, se comoveram com a fé vivida nos obscuros porões da repressão. Houve até momentos em que essas pessoas fizeram questão de participar da eucaristia celebrada com toda simplicidade no cárcere.

Outros se comprometeram na defesa da vida dos mais pobres e na luta incansável pela justiça, direitos humanos e direitos dos pobres. Faço menção aqui de alguns nomes: Dom Antônio Fragoso, bispo de Crateús, CE; o padre operário Domingos Barbé, da Pastoral Operária de São Paulo, morador da cidade de Osasco, por muitos anos assessor das CEBs; o teólogo Hubert Lepargneur, religioso da congregação dos Camilianos de São Paulo; o padre Alfredinho Kunz, que atuou junto a prostitutas na cidade de Crateús e foi um dos mais radicais praticantes da não-violência ativa no Brasil (Gilberto Carvalho, integrante da Pastoral Operária, ministro de Lula e da Presidenta Dilma Rousseff, foi particular amigo de Alfredinho e mantém foto dele em seu gabinete no Palácio do Planalto); Dom Pedro Casaldáliga, bispo da Prelazia de São Félix do Araguaia, perseguido por sua defesa dos povos indígenas no MT, mantido em prisão domiciliar em sua casa, nos inícios dos anos de 1970; Dom Tomás Balduíno, bispo de Goiás Velho, primeiro presidente da Comissão

\footnotetext{
24 CARDEAL ARNS, 1977, p. 89.

25 BETTO, Frei. Cartas da prisão. Rio de Janeiro: Civilização Brasileira, 1977. BETTO, Frei. Das catacumbas. Rio de Janeiro: Civilização Brasileira, 1978. Lembro que quando ainda estudante de teologia em 1973, recebemos estas cartas em panfletos mimeografados que eram passados de mão em mão, por ser material perigoso se caísse em mãos indevidas.
} 
Pastoral da Terra ${ }^{26}$; Dom Hélder Câmara, talvez o bispo mais conhecido na época por suas viagens internacionais em defesa da Paz e da Justiça, proibido e ameaçado diversas vezes pela Ditadura militar. Estive certa vez em sua residência, uma pequena casa nos fundos da Igreja das Fronteiras, num bairro do Recife, e pude ver os buracos das balas de uma metralhadora no muro da igreja e que foi acionada para intimidá-lo; o pastor Ricardo Wangen, da IECLB, professor na Escola Superior de Teologia e um dos pastores luteranos mais ativos no Movimento de Justiça e Paz, fundador da ONG SERPAZ, com sede em São Leopoldo, RS; o Pastor Bertholdo Weber, incansável líder ecumênico no Brasil e defensor dos direitos humanos, em especial, das crianças; o bispo anglicano Dom Sumio Takatsu, outra personalidade que ligou sua vida à luta pela paz e pelo ecumenismo. A lista é apenas indicativa e seria longa se pudesse aqui buscar documentos e histórias de vida. Mas não poderia deixar de mencionar ainda, com um profundo sentimento de gratidão, o Mosteiro Beneditino da Anunciação, que se localizava na zona rural de Curitiba nos anos de 1970, e depois transferido para Goiás Velho, GO. Com os monges aprendi a relação inextrincável entre oração e luta pela justiça, a leitura orante dos salmos e dos textos dos evangelho, a radicalidade da fé cristã.

Como luterano, preciso mencionar ainda duas experiências marcantes para a minha geração. A primeira tem a ver com um grupo de colegas, homens e mulheres, que apostaram no que então denominamos pastoral de convivência. Alguns foram trabalhar nas fábricas, outros para o meio rural, e outros ainda decidiram a caminhada junto aos povos indígenas. $\mathrm{O}$ objetivo foi inserir-se nos meios populares e a partir de baixo dar testemunho do evangelho que liberta e praticar a luta por justiça e transformação social na qual estávamos engajados desde os tempos de estudantes. Vários dentre nós acabaram por compor coordenações da Comissão Pastoral da Terra, do Conselho Indigenista Missionário, órgãos vinculados à $\mathrm{CNBB}$, mas ecumenicamente abertos para acolher nossa presença. Depois surgem na IECLB o COMIN - Conselho de Missão entre Povos Indígenas, a PPL - Pastoral Popular Luterana, o CAPA Centro de Apoio ao Pequeno Agricultor, e outras entidades que se tornaram a marca dos luteranos juntos aos movimentos populares. Nesse sentido, também merece destaque a atuação de ministros e leigos de igrejas evangélicas irmãs como a Igreja Metodista, a Igreja Episcopal Anglicana do Brasil, a Igreja Presbiteriana Independente do Brasil, a Igreja Presbiteriana Unida, além de

${ }^{26}$ Dom Tomás Balduíno faleceu em 02/05/2014, com quase 92 anos. Sua lembrança como pastor, discípulo de Jesus, lutador social e doutor da fé, como escreveu o monge Marcelo Barros, estará sempre conosco. 
pessoas de algumas igrejas pentecostais, que gradativamente vieram a assumir posturas mais críticas somando-se aos setores que lutaram pela redemocratização do país.

\section{CONSIDERAÇÕES FINAIS}

Esta é uma história que ainda precisa ser escrita, embora já tenhamos alguns estudos que nos ajudam a conhecer de perto alguns dos episódios que envolveram a participação de igrejas e pessoas cristãs na resistência à Ditadura civil-militar. Aqui procurei destacar alguns momentos dessa história, fazendo referência a pessoas e grupos, tendo consciência de que se trata de uma análise ainda inicial e sem pretensão maior que contribuir para pesquisas futuras.

O que se pode aprender dessa história é que a cada momento as pessoas tomam decisões e posicionam-se diante da conjuntura histórica vivida. Uns optam por defender e articular-se com os poderes dominantes; outros, por ligarem-se aos de baixo e por não se conformarem com as desigualdades, o uso da força e do arbítrio em nome da preservação da ordem e do progresso. Aqui não procurei julgar quem quer que seja. Mas cada qual deverá prestar contas à sociedade, à Igreja e ao seu Senhor de seus atos e das opções que orientam sua vida.

Para concluir apresento brevemente a concepção de não-violência ativa ou firmeza-permanente como foi vivida e defendida por Domingos Barbé, já falecido, importante articulador da pastoral operária em São Paulo e da luta não-violenta no Brasil. Barbé defendeu que havia três importantes razões para adotar na luta social brasileira os princípios da não-violência ativa27: a) $a$ psicologia do conflito, pela qual a resposta à violência de outrem é sempre o combate não-violento que se baseia na astúcia, na coragem e na permanente disposição de não matar nem humilhar o adversário; b) a perspectiva sociopolítica, fundamental para a análise do que está em jogo na luta social. Nesse caso, é importante preparar-se para a desobediência civil maciça e organizada (como fez Gandhi na Índia), e nunca depender de um líder carismático. Por isto Barbé sempre enfatizou: "a não-violência não se improvisa e ela não é somente uma espiritualidade”. Ela é um elemento constitutivo do evangelho e da vivência da cruz, reportando-se a Miguel D’Escoto e à luta de libertação na Nicarágua. Não-violência ativa não é submissão, antes é arriscar a

27 BARBÉ, Domingos. A graça e o poder: as comunidades eclesiais de base no Brasil. São Paulo: Paulinas, 1983. Barbé havia publicado nos anos de 1970 um "catecismo" para as CEBs no qual inseriu a luta por paz e justiça como central na vivência contemporânea da fé cristã. BARBÉ, Domingos. Fé e ação: catecismo para os cristãos das comunidades de base. 2. ed. São Paulo: Loyola, 1977. 
vida pela causa da justiça e da fraternidade. Nas palavras de D'Escoto: “Quando fazemos isso, sofremos represália dos que oprimem os outros. Isso é a cruz. Quando suportamos a cruz, participamos das dores da concepção de Cristo que sofre violência para gerar a nova humanidade"; c) a perspectiva propriamente teológica, que remete à prática do amor como radicalizada por Cristo no amor aos inimigos (Lucas 6.27ss). A questão se renova em cada época e se poderia resumir na pergunta: como traduzir este mandamento de Cristo em nossa realidade de violência e crueldade sem medida? Barbé lembrava que o próprio Gandhi afirmou certa vez: "se não podes ser não-violento, sê violento. O que não podes ser é omisso, abster-te de tomar posição diante da injustiça”. De qualquer forma, a não-violência ou firmeza-permanente não faz concessão ética à violência. A transformação radical da humanidade supõe vencer a violência com a não-violência, fazendo com que a vida prevaleça sobre a morte. Por isto o poder da não-violência é o poder da ressurreição. Ela traz e anuncia o desafio para uma vida em prol da humanidade, de todas as pessoas, boas ou ruins, sem pretender messianicamente separar antes do tempo o joio do trigo. Este julgamento pertence ao Doador da Vida e não a nós, simples mortais. Esta força de vida é uma força regeneradora que projeta sobre a sociedade um clarão que ilumina as injustiças e desafia a construir caminhos de paz e justiça. Esta é uma experiência extraordinária que só acontece a partir da graça de Deus. É, portanto, na gratuidade da experiência proporcionada pela firmeza-permanente que encontramos novas possibilidades de vida e de transformação da história.

\section{REFERÊNCIAS}

ALVES, Márcio Moreira. Torturas e torturados. Rio de Janeiro: Idade Nova, 1966.

O Cristo do Povo. Rio de Janeiro: Sabiá, 1968.

BARBÉ, Domingos. A graça e o poder: as comunidades eclesiais de base no Brasil. São Paulo: Paulinas, 1983.

Fé e ação: catecismo para os cristãos das comunidades de base. 2. ed. São Paulo: Loyola, 1977.

BETTO, Frei. Cartas da prisão. Rio de Janeiro: Civilização Brasileira, 1977.

Das catacumbas. Rio de Janeiro: Civilização Brasileira, 1978.

BRASIL NUNCA MAIS. Prefácio de Dom Paulo Evaristo Arns (1985). 13. ed. Petrópolis: Vozes, 1986.

CÂMARA, Dom Hélder. Revolução dentro da Paz. Rio de Janeiro: Sabiá, 1968. 
CARDEAL ARNS, Dom Paulo Evaristo et al. A firmeza-permanente: a força da nãoviolência. São Paulo: Loyola/Vega, 1977.

CASALDÁliGA, Dom Pedro. Creio na justiça e na esperança. Rio de Janeiro: Civilização Brasileira, 1978.

Antologia retirante. Poemas. Rio de Janeiro: Civilização Brasileira, 1978.

CONY, Carlos Heitor. O ato e o fato. Crônicas políticas. Rio de Janeiro: Civilização Brasileira, 1964.

GUIMARÃES, Marcelo Rezende. Educação para a paz: sentidos e dilemas. Caxias do Sul: Educs, 2005.

HARPER, Charles R. El acompañamiento; acción ecuménica por los derechos humanos en América Latina 1970-1990. Ginebra/Montevideo: Consejo Mundial de Iglesias e Ediciones Trilce, 2007.

PADILHA, Anivaldo Pereira. Reflexões sobre medidas de verdade: do Brasil Nunca Mais a uma comissão da verdade. In: Caminhando. São Bernardo do Campo, v. 16, $\mathrm{n}^{\mathrm{o}}$ 1, p. 165-170, jan/jul 2011.

REIS, Daniel Aarão. Ditadura e democracia no Brasil. Do golpe de 1964 à Constituição de 1988. Rio de Janeiro: Zahar, 2014.

SCHÜNEMANN, Rolf. Do gueto à participação; a emergência da consciência sóciopolítica na Igreja Evangélica de Confissão Luterana no Brasil entre 1960 e 1975. São Leopoldo: Sinodal, EST/IEPG, 1992.

TAVARES, Flávio. 1964. O golpe. Porto Alegre: L\&PM, 2014.

VENTURA, Zuenir. 1968 - O ano que não terminou. 12. ed. Rio de Janeiro: Nova Fronteira, 1988. 